\title{
Customer Satisfaction Evaluation on Tokopedia E-Commerce Platform under Belt and Belt and Road Initiative
}

\author{
Carmelia Devina* Zhang Lei Guan Gaofeng, \\ Department of International Business Management, \\ Zhejiang University of Science \& Technology, Hangzhou PR. CN. \\ Carmeliadevinaa01@gmail.com
}

\begin{abstract}
This research intended to study the Customer Satisfaction Evaluation on Tokopedia E-Commerce Platform under Belt and Road Initiative where this is based on the dimensions of performance, features, reliability, conformance, durability, serviceability, aesthetics, and perceived quality. The method used in this research is observation, questionnaires, and literature. While for the data analysis technique used is Multiple Linear Regression Analysis. The author takes an object of research in the year 2021 with a total sample of 358 respondents. Data collection technique that is adopted is convenience sampling method. The author distributed the questionnaires with 39 questions using dimensional performance, feature, reliability, conformance, durability, serviceability, aesthetics, and perceived quality. Belt and Road Initiative (BRI) through Indonesia's E-Commerce Platform Tokopedia, Performance (X1), Reliability (X2), Feature (X3), Conformance (X4), Durability (X5), Serviceability (X6), Aesthetics (X7), Perceived Quality (X8) simultaneously affects the dependent variable Customer Satisfaction (Y). The percentage of the influence of the independent variables on the dependent variable is shown by the coefficient of simultaneous determination (R2). In this study, the magnitude of the R Square is 0.979. This means that the rise and fall of the dependent variable, namely performance $(\mathrm{Y})$, is influenced by the independent variables, namely Performance (X1), Reliability (X2), Feature (X3), Conformance (X4), Durability (X5), Serviceability (X6), Aesthetics (X7), Perceived Quality (X8) by $97.9 \%$ while the remaining 2.1 percent is influenced by other variables outside of this study. There is a positive significant influence of Belt and Road Initiative (BRI) through the Product Quality towards the Customer Satisfaction Evaluation of Tokopedia Indonesia.
\end{abstract}

Keywords: Belt and Road (BRI), Customer Satisfaction, Product Quality, Tokopedia

DOI: $10.7176 / \mathrm{JESD} / 12-6-02$

Publication date:March $31^{\text {st }} 2021$

\section{Introduction}

Indonesians are the most enthusiastic people in the world when it comes to accepting digital technology and social media such as Instagram, Facebook, YouTube and Twitter. Indonesia has the billion tech startups in Southeast Asia, including Tokopedia, Bukalapak, Go-Jek, Lazada, Traveloka, etc. Indonesia, being one of the fastest growing economies in the Southeast Asian region is developing on success and is expected to grow \$200 Billion by 2025 , According to a Google and Temasek report. E-commerce in Indonesia has socioeconomic impact in four areas: financial benefits, job creation, buyer benefits, and social equality. Nowadays, e-commerce platform has begun to make differences in the international market to pursue a domestic development and at the same time, to increase market share and expand foreign markets, e-commerce companies often began to expand development abroad. Relationship between Indonesia and China have been built for centuries, which was originally started because of the Maritime Silk Road's existence. Throughout the years, Chinese government has turned Maritime Silk Road into Belt and Road Initiative. Under the Belt and Road Initiative, Alibaba (the largest e-commerce platform in Southeast Asia) has been capable of investing in Indonesia's e-commerce platform easily. In an effort to enhance and expand the Alibaba market, Alibaba deepens the integration of its ecosystem by investing a total of $\$ 1.1$ billion in Tokopedia. Tokopedia is considered to be the largest e-commerce marketplace in the Indonesian region. By surveying Tokopedia platform's users, we can find out how the actual condition of the Tokopedia market place is and what could be improved under the collaboration of Indonesia - China belt and road initiative using Customer Satisfaction. We know that Indonesia is a big maritime country and also the world's largest island country, which makes it hard to move from one island to another island. Therefore, using Customer Satisfaction we want to concentrate more on whether or not all of the circumstances affect the market place of Tokopedia platform, also to analyze how The Belt and Road Initiative has brought significant impacts to the market place of LAZADA platform, and offer some possible suggestions related to the above circumstances. It's so intriguing for the researcher using Customer Satisfaction to analyze if the Belt and Road Initiative could deliver impacts on the development of e-commerce in Indonesia, and to be able to also initiate some possible suggestions to enlarge the e-commerce marketplace in Indonesia especially Tokopedia platform. The Belt and Road Initiative, as we known as Belt and Road Initiative aims to encourage relations connectivity between China with the world. Also, China aims to encircle countries in the ancient overland Silk Road and new maritime Silk Road in interconnected infrastructure to bring them closer into China's realm of influence and provide a host of mutual benefits to China 
and the affected countries. China offers long-term, low-interest loans to governments and often provides the lowest priced skilled labor required for those projects. Relations between China and Indonesia have existed for centuries. Indonesia has a strategic location and one of the countries who participated in the Belt and Road Initiative. As we know the new round of technological revolution is underway, new economic activities, such as e-commerce, big data, cloud computing, AI, mobile payment and others, are creating new room for future cooperation between China and Indonesia. Alibaba Group invested in one of Indonesia's largest e-commerce platforms Tokopedia and built the Indonesian version of "Taobao". Up to today, Belt and Road has been giving a significant impact on Indonesia's economy in general. In a nutshell, Tokopedia has been holding a vital role in Indonesia as one of the biggest e-commerce platforms in the country. Therefore, there must be some good influences that Belt and Road Initiative has made on Tokopedia's development in Indonesia.

\section{Literature Review}

\subsection{Customer Satisfaction}

Customer Satisfaction is the most significant factor in a marketing field report. It has been claimed that customer Satisfaction is a casual factor [16], when the customer decides to pursue or postpone transactions with an online distributor [17]. Satisfaction is the estimation of the amazement related to the decision to purchase the product and the enjoyment in the use of the goods and services [18].

\subsubsection{Customer Satisfaction Indicator}

Satisfaction in this study is measured through intermediate indicators others: Service, Price, and Product Variety Service Quality

It is an assessment of how well a company meets the expectations of its clients. The consistency of the service depends on the degree to which the needs of a given product are met. Satisfied and faithful buyers have been an important part of retailing for years. When the customer is happy with the services provided by the shop, they become loyal. Loyal consumers make a positive contribution to the development of a sustainable strategic edge over rivals. In marketing, the role of the benefit of the consumer has researched for 20 years [10].

However, the efficiency of the service can be calculated by five factors: Tangibility, Reliability, Responsiveness, Assurance, Empathy [11].

- Tangible includes the availability of staff and the physical features provided to the customer to maximize customer loyalty.

- $\quad$ Reliability is the ability to produce and deliver the promised quality of service with maximum consistency without any modification. It promised to be delivered the same way.

- Responsiveness explains the amount of interest needed to fix challenges and help the consumer react quickly to their problems.

- Assurance is the level of empathy and the behaviors of the employees of the organization towards their customers.

- Empathy means respecting the consumer, giving attention to the customer and taking care of the customer.

Price

The perceived price can be described as an association between the price and the value that the consumer has achieved from the purchase of the product [12]. Price is known to be a major element in consumer loyalty [13]. Customers analyze the worth of the commodity according to its price metric. So, if the price of the goods is too high, it could be likely that the buyer would not purchase the product and lose its needs. The cheaper the cost of the commodity, the smaller the customer's expenses would be [12]. Price plays a key role in the minds of shoppers as it affects customer satisfaction and their purchasing behaviors [14].

\section{Product Variety}

Offering a wide range of goods is also the secret for online traders to keep buyers coming in. With a lot of options, there would be a better probability of selling the product. Online retailers that have delivered a wide range of options and choices tend to be more popular [4]. Customers expect online stores to deliver a diverse range of products due to the scope of the Internet and the opportunity for tracking niche goods and services [2]. It was also suggested that a broader range of items could be appealing to customers satisfaction and that e-satisfaction would be more favorable if online retailers deliver superior product assortments [15].

\section{Product Quality}

Product Quality is closely linked to the customer satisfaction. Quality is an essential part of a product and it is also known as the expected product or service excellence benchmark [2]. The influence of a high-quality product was highlighted in the Sproles and Kendall Consumer Style Inventory (CSI) models. Some consumers consider quality to be their first consideration when they shop online [3]. Although online shopping cannot allow consumers to directly touch or feel the quality of the product, comments on the website may, to some extent, indicate the quality of the product. In the light of [4], a joint analysis of consumer preferences based on data collected from 188 young consumers reveals that privacy (technology factor), merchandising (product factor) and convenience are the three most important attributes for online consumer satisfaction (shopping factor). Improving product quality will have 
a positive effect on improving consumer satisfaction [4]. If a company wants to maintain its competitive advantage in the market, the company must understand what dimensions are used by consumers to differentiate the products the company sells from competitors' products [1]. The dimensions of product quality consist of:

a. Performance

b. Durability

c. Feature

d. Conformance to specifications

e. Reliability

f. Serviceability

g. Aesthetics

h. Perceived quality

\subsection{Background of Belt and Road Initiative}

Initially announced in 2013 with the aim of restoring the ancient Silk Route linking Asia and Europe, the scope of the project has been extended over the years to include new territories and development initiatives [5]. Formerly known as the Belt and Road Initiative (Chinese: over, short for the Silk Road Economic Belt and the 21st-century Maritime Silk Road) has been referred to as the Belt and Road Initiative (BRI) since 2016, when the Chinese government considered the importance on the word "one" to be misrepresented. However, the term "One Belt One Road" is indeed the reference term in Chinese-language media. The goal of the Belt and Road Initiative is to foster ties of connectivity between China and the world. The Belt and Road Initiative fills the infrastructure deficit and hence has the ability to stimulate economic development across Asia-Pacific, Africa and Central and Eastern Europe. The project builds on the old trade routes that once connected China to the west, Marco Polo's and Ibn Battuta's Silk Road to the north, and Admiral Zheng He's maritime expedition routes to the south. The project includes the construction of a large network of roads, bridges, marine ports, power grids, oil and gas pipelines and related transport ventures. While some countries consider the project negatively because of potential Chinese interference, others point to the development of a new global growth driver by linking and bringing Asia, Europe and Africa closer together. China's Belt and road goals are policy alignment, infrastructure connectivity, unimpeded commerce, financial inclusion, and people-to-people connectivity. China also seeks to encircle countries in the ancient overland Silk Road and the modern maritime Silk Road in interconnected infrastructure, bringing them closer to China's sphere of influence and providing China and the affected countries with a range of reciprocal benefits. China offers long-term, low-interest loans to governments and also provides the lowest cost qualified labor required for such projects. The impact of belt and road for Indonesia is already very visible, but also with the relationship of belt and road has a big impact for Tokopedia e-commerce platform.

Tokopedia also made China a source of imported goods for Indonesia, which can be proven by the cooperation to make Tokopedia get investment from Alibaba in the amount of 1.1 billion. From the relationship and the impact given from the belt and road for Indonesia, it can be concluded that the belt and road is very beneficial for the Indonesian state in all aspects. Alibaba as one of the e-commerce giants in China is not only linking local digital businesses and networks in Asia with China-centric digital technology, but is also exporting a Chinese edition of the new world order. But Alibaba is not alone in transferring influence to Chinese digital channels. Tencent, Alibaba's biggest rival, has been busy taking part in the Asia-Pacific digital payment and ridehailing networks. Its all-in-one mega-social media site, WeChat, reached 1 billion global accounts in 2018. Any of the development came from Southeast Asia, Europe, and the United States. JD.com (with Tencent as its largest shareholder) has also been involved in the Asia-Pacific region: setting up offices in Melbourne, Australia (2017) and South East Asia (Indonesia, 2016); participating in the Vietnamese ecommerce giant Tiki.vn; and establishing a joint venture with the Thai retailer, Central Group. Bytedance has stormed Asia with its TikTok/Douyin video sharing software (as known in China) [6]

These are only a few indicators of how China's emerging channels are forming what we call China's digital revolution. The new digital Silk Road relies on a China-centric digital infrastructure, including e-roads, e-hubs, R\&D centers and logistics centers [7]. As a result, we have seen a huge deployment of capital, from land (the overland Silk Road) to sea (the Maritime Silk Road), from underground and underwater cables to the Space Information Corridor (via its BeiDou satellite network), from high-speed rail tracks to telecommunications and ecommerce networks along the Belt and Road Initiative program.

E-commerce, on the other hand, is a sector where we can see indications of China's significant progress. A variety of Southeast Asian-based platforms have built up a reputation as price-conscious and trustworthy, such as Tokopedia and Lazada. In addition, Alibaba Taobao entered the Singaporean market in 2013. It now owns a majority interest in two of the most successful e-commerce sites in South East Asia: Lazada and Tokopedia. Whereas, on the 8th anniversary of Tokopedia, 17 August 2017, Tokopedia acquired a $\$ 1.1$ billion funding from Alibaba, where it became a minority shareholder [8]. Tokopedia is the first e-commerce site in Southeast Asia to thrive on securing financing from Softbank and Sequoia Capital in the amount of US\$100 million. Financial times 
predicted that Indonesia's first single-corn e-commerce website or start-up with a value of more than \$billion dollars will include two e-commerce start-ups with $\mathrm{C} 2 \mathrm{C}$ business models: Bukalapak and Tokopedia [9]. Tokopedia is Indonesia's largest e-commerce market with US\$7 billion of the overall GMV and becoming one of the top ten unicorns in Southeast Asia (May, 2019). Founded by William Tanuwijaya and Leontinus Alpha Edision on the 17th of August 2009 which also coincides with Indonesian Independent's Day.

The author found that the majority of the research in e-commerce platforms today focuses mostly on the topic of satisfaction of customers itself. Presently, e-commerce platforms such as Tokopedia received a great positive impact from the belt and road initiative, as ties between Indonesia and China become stronger. Indirectly, Belt and Road initiative have helped Tokopedia in increasing customer loyalty in several ways. However, there is no research that explores the effect of belt and road initiative on customer satisfaction towards through the Chinese product quality Tokopedia. This study focuses mainly on how Product Quality can impact Tokopedia consumer satisfaction under the belt and road initiative.

\subsection{Conceptual Framework}

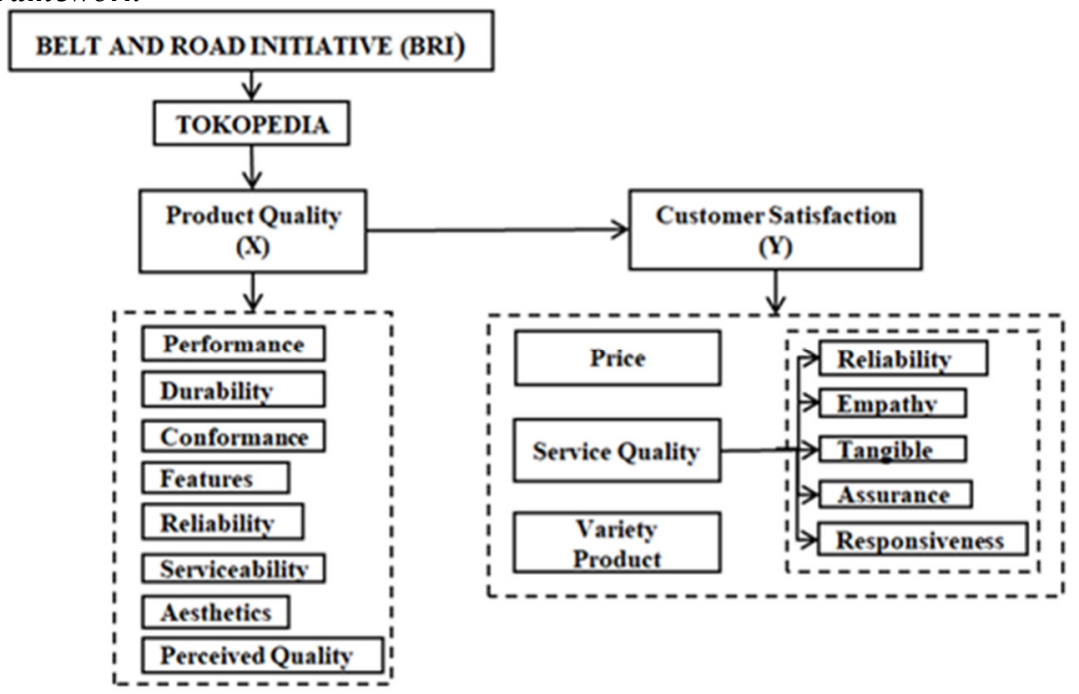

\subsubsection{Hypothesis Development}

Figure 1: Conceptual Framework

H1: There is a significant influence of Performance (X1) to the Customer Satisfaction (X1) partially

- Performance of the Products (made In China) that are offered through the E-commerce Platform, Tokopedia plays a crucial role in determining satisfaction of the customers [1].

H2: There is a significant influence of Reliability (X2) to the Customer Satisfaction partially

- Reliability refers to products' level of usefulness which therefore, can be understood that the level of usefulness of the products (made in China) offered in Tokopedia [1]

H3: There is a significant influence of Feature (X3) to the Customer Satisfaction partially

- Feature in this study refers to the added value to the products (made in China) offered in Tokopedia [1]

H4: There is a significant influence of Conformance (X4) to the Customer Satisfaction partially

- Conformance in this research refers to the conformance to a specified standard of products (made in China) offered in Tokopedia [1]

H5: There is a significant influence of Durability (X5) to the Customer Satisfaction partially

- Durability can be understood as the capacity of the product to be able to function well normally over the course of its design lifespan without needing unnecessary maintenance or repair [1]

H6: There is a significant influence of Serviceability (X6) to the Customer Satisfaction partially

- In this case, Serviceability refers to how adequate is the service offered by the seller of the products (made in China) in Tokopedia to the customers [1]

H7: There is a significant influence of Aesthetics (X7) to the Customer Satisfaction partially

- In this study, Aesthetics refers to the various forms of the products offered as well as the neatness and the refinement of the products (made in China) offered in Tokopedia [1]

H8: There is a significant influence of Perceived Quality (X8) to the Customer Satisfaction partially

- In reference of this research study, perceived quality is known to be the consumer's impression after using the product itself. Products that can work well and in accordance with the expectations or perceptions of consumers will create a good impression, because consumers are satisfied with the product's performance [1] 
H9: Belt and Road Initiative (BRI) through Indonesia's E-Commerce Platform Tokopedia, Performance (X1), Reliability (X2), Feature (X3), Conformance (X4), Durability (X5), Serviceability (X6), Aesthetics (X7), Perceived Quality (X8) simultaneously affects the dependent variable Customer Satisfaction (Y).

\subsection{Research Method}

Research design that is adopted in this study is the hypothesis research. Research design which is conducted in this study is a survey to examine the customer satisfaction evaluation of Tokopedia under Belt and Road initiative.

Scale

The author decided to adopt the Likert scale which is mostly used to evaluate the score of each question in the questionnaires. The scales are segmented into five different categories which are denoted numerically ranging from 1 to 5 with 1 as very disagree, 2 as disagree, 3 as Neutral, 4 as Agree, 5 as Very Agree.

The respondents would then be asked to answer the questions stated in the questionnaires. The number of questions in questionnaires answered will then be summed together and the final score is then labeled as the final score that shows the opinion of the respondents towards the variables.

\subsection{Sampling Design \\ 3.2.1 Population}

The population that is adopted for this research will be the customers who have ever used the Indonesian Ecommerce platform namely, Tokopedia and have at least made a transaction once. The gender of the customers will also be asked in the questionnaires whereas the age distribution will be specified according to all ages differentiated by range of ages that is classified according to the age groups. The questionnaires are distributed to the first 40 people which are spreads among the existing social Medias such as WeChat, WhatsApp, Instagram, and other available application that can be utilized.

\subsection{Sampling Size}

In this research the sample size that will be decided from the number of questions that are conceived in the questionnaires. And the samples of this research are the respondents who have ever made a purchase at least once through the e-commerce platform, Tokopedia residing in Indonesia. The amount of sample size that should be accumulated can be approximated multiplying the number of conceived questions in the questionnaires by the number from five to ten. Since the conceived number of questions in the questionnaires is 39 therefore, the minimum number of respondents that should be obtained would be about $195(39 \times 5=135)$ respondents whereas the maximum number of questionnaires that should be distributed is approximately around $390(39 \times 10=390)$ respondents which are Indonesian consumers who have used Tokopedia.

\subsubsection{Variable Identification}

A. Independent variables are the dimensions of Product Quality such as Performance (X1), Reliability (X2), Feature (X3), Conformance (X4), Durability (X5), Serviceability (X6), Aesthetics (X7), Perceived Quality (X8).

B. Dependent variable that is adopted in this study is Customer Satisfaction (Y)

\subsubsection{Operational Definition of Variables}

1. Performance (X1), Relating to the characteristics and performance of the product itself in its operation.

2. Reliability (X2), Relates to the service life of the product itself, the durability and strength of the product in a certain period of time.

3. Feature (X3), adds to the basic functionality of options and their development.

4. Conformance (X4), This dimension describes how the product works optimally according to its specifications.

5. Durability (X5), Various possibilities of these products will work well in a certain period of time. The less likely the product is to be damaged over a long period of time, the better the product will provide customer satisfaction.

6. Serviceability (X6), Namely the speed and ease of service provided as well as the competence and friendliness of service staff.

7. Aesthetics (X7), It has to do with the outer appearance of the product itself. This appearance concerns the characteristics and model or shape of the product itself.

8. Perceived Quality (X8), Refers to the consumer's impression after using the product itself. Products that can work well and in accordance with the expectations or perceptions of consumers will create a good impression, because consumers are satisfied with the product's performance. The implication is that consumers will be loyal to the company's products. Conversely, if the product does not work in accordance with consumer expectations, the consumer will feel less satisfied.

\section{0 Findings}

The sample populations in this study are all Indonesian from various occupations and genders who have at least made a purchase in Tokopedia. The respondents' data that have been accumulated are compiled according to the 
respective genders, age, income level, Occupation and the results are shown in the following:

\section{A. Gender distribution level among respondents}

Table 1: Gender distribution level

\begin{tabular}{|l|c|c|}
\hline \multicolumn{1}{|c|}{ Gender } & Respondents & Percentage \\
\hline Male & 166 & 46.2 \\
\hline Female & 193 & 53.8 \\
\hline
\end{tabular}

Source: Primary data (2021)

Figure 2: Gender distributions among respondents

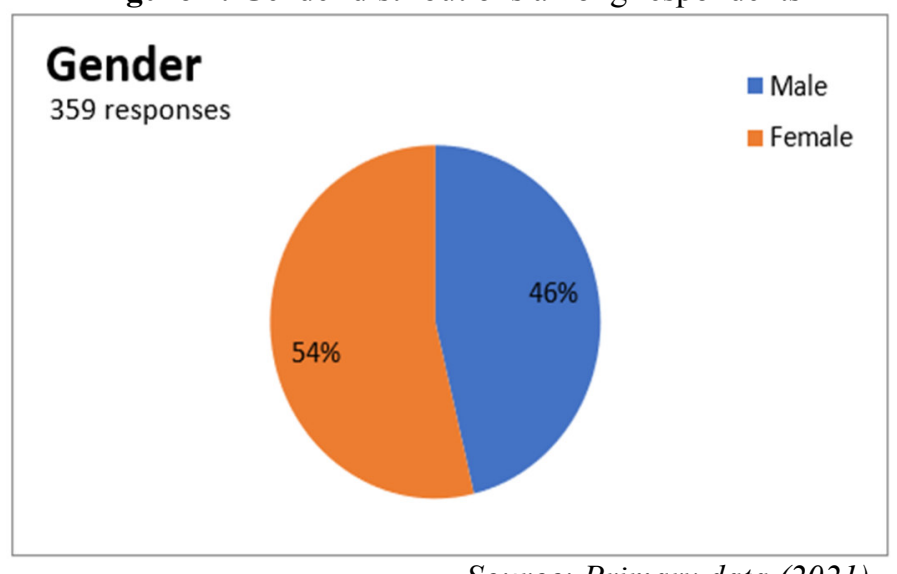

Source: Primary data (2021)

According to the Figure 2, it can be seen that the gender distribution of among Tokopedia users can be deduced that there are more female respondents than the male respondents, $54 \%$ and $46 \%$ respectively.

\section{B. Age distribution level among respondents}

Table 2: Age distribution level

\begin{tabular}{|l|c|c|}
\hline Age & Respondents & Percentage \\
\hline $17-25$ tahun & 239 & 66.6 \\
\hline $26-35$ tahun & 71 & 19.8 \\
\hline $36-45$ tahun & 12 & 3.3 \\
\hline$>45$ tahun & 36 & 10.0 \\
\hline
\end{tabular}

Source: Primary data (2021)

Figure 3: Age distributions among respondents

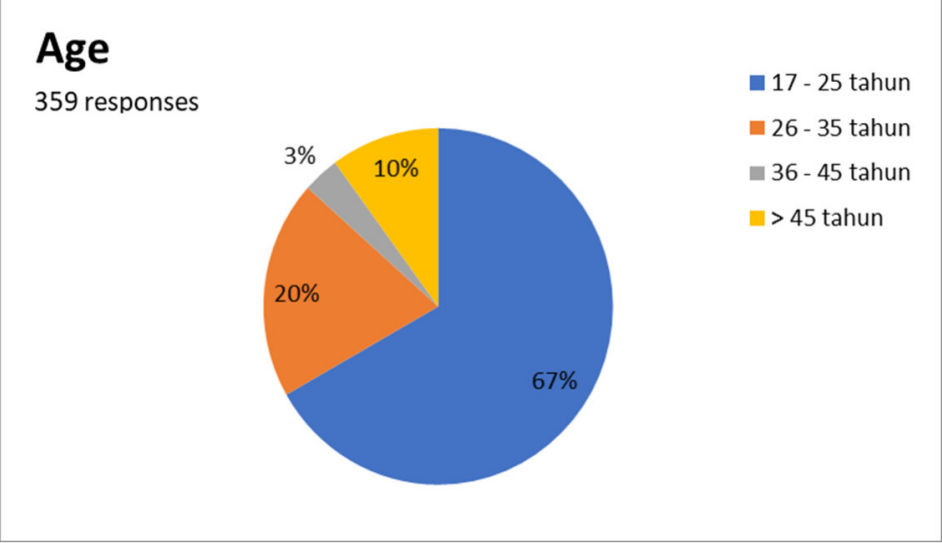

Source: Primary data (2021)

From the diagram shown in Figure 3, it can be seen that the age distribution among the respondents is dominated by age group from $16-25$ years old at $67 \%$, followed by the age group ranging from $26-35$ years old at $20 \%$, then the age group of $36-45$ years old at $10 \%$ with the last place occupied by the age group above 45 years old at only about $3 \%$. From the above age group user's distribution, it logical that the dominating users is from the age group of $17-25$ which can also be labeled as the young adults since in this age group, they seemed 
to be highly familiar or more technology savvy when operating e-commerce platforms such as Tokopedia as compared to other older age groups.

\section{Income level distributions among respondents}

Table 3: Income level

\begin{tabular}{|l|c|c|}
\hline Income Level & Respondents & Percentage \\
\hline$<5.000 .000$ rupiah & 175 & 48.7 \\
\hline $5.000 .000-10.000 .000$ & 120 & 33.4 \\
\hline$>10.000 .000$ rupiah & 64 & 17.8 \\
\hline
\end{tabular}

Source: Primary data (2021)

Figure 4: Income level distributions among respondents

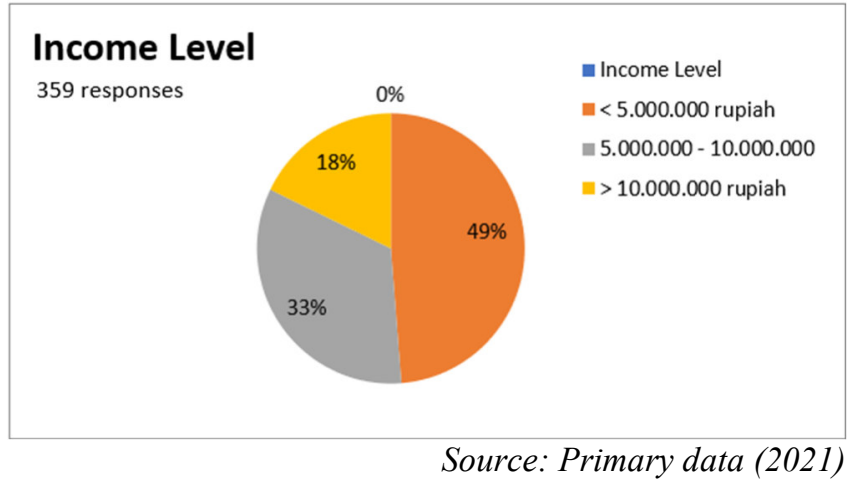

\section{Occupation distributions among respondents}

Table 4: Occupation distributions

\begin{tabular}{|l|c|c|}
\hline Occupation & Respondents & Percentage \\
\hline Housewives & 8 & 2.2 \\
\hline University Student & 154 & 42.9 \\
\hline Government Employees & 22 & 6.1 \\
\hline Private Employees & 100 & 27.9 \\
\hline Entrepreneur & 75 & 20.9 \\
\hline
\end{tabular}

Source: Primary data (2021)

Figure 5: Occupation level distributions among respondents

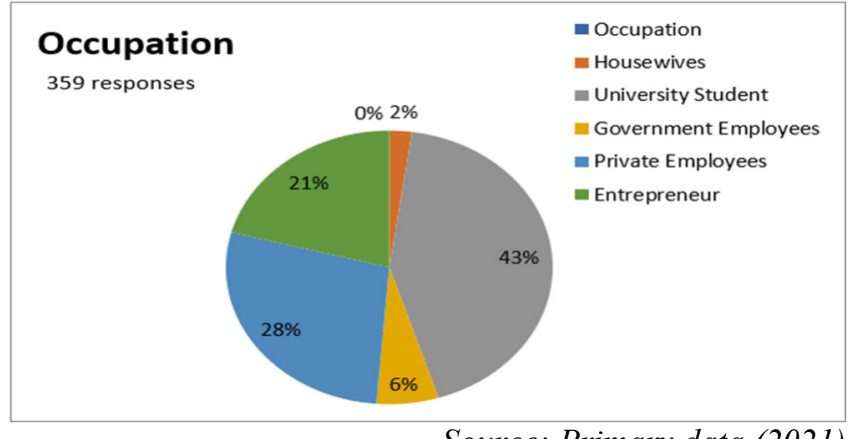

Source: Primary data (2021)

According to the Figure 5, it is known that the majority of the respondents regardless of the gender are University students at about $43 \%$, followed by Private Employees 28\%, then Entrepreneur at 21\%, the second last placed which is secured by the government employees at only $6 \%$ with Housewives groups at a merely $2 \%$. From here it can be concluded that University students are more active or has a higher exposure level towards the utilization of the e-commerce platform since University students tends to be more technology-savvy towards the e-commerce platforms as compared to other occupation groups. 


\section{E. Reliability and Validity Analysis \\ Validity Analysis}

A study that measures its variables through the use of questionnaires must undergo the data quality analysis. There are 2 requirements for the questionnaires to be valid and reliable, thus the author adopted the Reliability and validity method for the purpose to ensure the accuracy of the questionnaires when conducting the study. For the data to be valid the criteria are:

- $\mathrm{R}_{\text {value }}$ must be greater than $\mathrm{R}_{\text {table }}$

- Significant value has to be lower than 0.05

Table 5: Validity test result towards the Product Quality variable

\begin{tabular}{|c|c|c|c|c|c|c|}
\hline $\begin{array}{c}\text { Main } \\
\text { Variable }\end{array}$ & Sub-Variables & Questionnaire & Sig. $<0.05$ & Rvalue & > Rtable & Remarks \\
\hline \multirow{17}{*}{$\begin{array}{l}\text { Product } \\
\text { Quality }\end{array}$} & \multirow{3}{*}{$\begin{array}{l}\text { Performance } \\
\text { (X1) }\end{array}$} & $\mathrm{X} 1.1$ & 0.000 & 0.695 & 0.1354 & Valid \\
\hline & & $\mathrm{X} 1.2$ & 0.000 & 0.562 & 0.1354 & Valid \\
\hline & & $\mathrm{X} 1.3$ & 0.000 & 0.737 & 0.1354 & Valid \\
\hline & \multirow{2}{*}{$\begin{array}{c}\text { Reliability } \\
\text { (X2) }\end{array}$} & $\mathrm{X} 2.1$ & 0.000 & 0.711 & 0.1354 & Valid \\
\hline & & $\mathrm{X} 2.2$ & 0.000 & 0.75 & 0.1354 & Valid \\
\hline & \multirow{2}{*}{$\begin{array}{l}\text { Features } \\
\text { (X3) }\end{array}$} & $\times 3.1$ & 0.000 & 0.725 & 0.1354 & Valid \\
\hline & & $\mathrm{X} 3.2$ & 0.000 & 0.769 & 0.1354 & Valid \\
\hline & \multirow{2}{*}{$\begin{array}{c}\text { Conformance } \\
\text { (X4) }\end{array}$} & $\times 4.1$ & 0.000 & 0.797 & 0.1354 & Valid \\
\hline & & $\times 4.2$ & 0.000 & 0.816 & 0.1354 & Valid \\
\hline & \multirow{2}{*}{$\begin{array}{l}\text { Durability } \\
\text { (X5) }\end{array}$} & $\times 5.1$ & 0.000 & 0.646 & 0.1354 & Valid \\
\hline & & X5.2 & 0.000 & 0.611 & 0.1354 & Valid \\
\hline & \multirow{2}{*}{$\begin{array}{l}\text { Serviceability } \\
\text { (X6) }\end{array}$} & $\mathrm{X} 6.1$ & 0.000 & 0.661 & 0.1354 & Valid \\
\hline & & $\mathrm{X} 6.2$ & 0.000 & 0.685 & 0.1354 & Valid \\
\hline & \multirow{2}{*}{$\begin{array}{c}\text { Aesthetics } \\
X(7)\end{array}$} & $\mathrm{X} 7.1$ & 0.000 & 0.77 & 0.1354 & Valid \\
\hline & & $\mathrm{X} 7.2$ & 0.000 & 0.651 & 0.1354 & Valid \\
\hline & \multirow{2}{*}{$\begin{array}{c}\text { Perceived } \\
\text { Quality (X8) }\end{array}$} & $\mathrm{X} 8.1$ & 0.000 & 0.797 & 0.1354 & Valid \\
\hline & & $\mathrm{X} 8.2$ & 0.000 & 0.816 & 0.1354 & Valid \\
\hline
\end{tabular}

Source: Primary data (2021)

According to validity results shown in table 5 , the variable product quality is further divided into 8 different indicators that are further separated into several statements that will assist in determining the accuracy of the indicators. It can be seen that the $\mathbf{R}_{\text {value }}$ of each statement is greater than the $\mathbf{R}_{\text {table }}$ and the significant value is 0.000 which can be interpreted that each and every statement in the questionnaires are valid and eligible in determining the variable Y (Customer Satisfaction).

Table 6: Validity test result towards the Customer Satisfaction variable

\begin{tabular}{|c|c|c|c|c|c|c|}
\hline $\begin{array}{c}\text { Main } \\
\text { Variable }\end{array}$ & Sub-Variables & Questionnaire & Sig. $<0.05$ & Rvalue > & $>$ Rtable & Remarks \\
\hline \multirow{18}{*}{$\begin{array}{l}\text { Customer } \\
\text { Satisfaction }\end{array}$} & \multirow{3}{*}{$\begin{array}{l}\text { Service Quality } \\
\text { (Tangible) }\end{array}$} & Y1 & 0.000 & 0.675 & 0.135 & Valid \\
\hline & & Y2 & 0.000 & 0.756 & 0.135 & Valid \\
\hline & & Y3 & 0.000 & 0.691 & 0.135 & Valid \\
\hline & \multirow{4}{*}{$\begin{array}{l}\text { Service Quality } \\
\text { (Reliability) }\end{array}$} & Y4 & 0.000 & 0.705 & 0.135 & Valid \\
\hline & & Y5 & 0.000 & 0.618 & 0.135 & Valid \\
\hline & & Y6 & 0.000 & 0.746 & 0.135 & Valid \\
\hline & & $\mathrm{Y} 7$ & 0.000 & 0.690 & 0.135 & Valid \\
\hline & \multirow{2}{*}{$\begin{array}{c}\text { Service Quality } \\
\text { (Responsiveness) }\end{array}$} & Y8 & 0.000 & 0.750 & 0.135 & Valid \\
\hline & & Y9 & 0.000 & 0.744 & 0.135 & Valid \\
\hline & \multirow{3}{*}{$\begin{array}{l}\text { Service Quality } \\
\text { (Assurance) }\end{array}$} & $\mathrm{Y} 10$ & 0.000 & 0.710 & 0.135 & Valid \\
\hline & & Y11 & 0.000 & 0.684 & 0.135 & Valid \\
\hline & & Y12 & 0.000 & 0.730 & 0.135 & Valid \\
\hline & \multirow{2}{*}{$\begin{array}{l}\text { Service Quality } \\
\text { (Empathy) }\end{array}$} & $\mathrm{Y} 13$ & 0.000 & 0.648 & 0.135 & Valid \\
\hline & & $\mathrm{Y} 14$ & 0.000 & 0.592 & 0.135 & Valid \\
\hline & \multirow{2}{*}{ Price } & Y15 & 0.000 & 0.631 & 0.135 & Valid \\
\hline & & Y16 & 0.000 & 0.636 & 0.135 & Valid \\
\hline & \multirow{2}{*}{ Variety Product } & Y17 & 0.000 & 0.758 & 0.135 & Valid \\
\hline & & Y18 & 0.000 & 0.699 & 0.135 & Valid \\
\hline
\end{tabular}

Source: Primary data (2021)

According to validity results shown in Table 6, the variable Customer Satisfaction is further divided into 7 different indicators that are further separated into several statements that will assist in determining the accuracy of the indicators. It can be seen that the $\mathrm{R}_{\text {value }}$ of each statement is greater than the $\mathrm{R}_{\text {table }}$ and the significant value is 
0.000 which can be interpreted that each and every statement in the questionnaires are valid and eligible.

D Reliability Analysis

There are 2 requirements for the questionnaires to be valid and reliable, thus the author adopted the Reliability and validity method for the purpose to ensure the accuracy of the questionnaires when conducting the study. For the data to be reliable, the criteria is that the Cronbach's Alpha has to be greater than 0.6

Table 7: Reliability test result towards the Product Quality variable

\begin{tabular}{|c|c|c|c|c|}
\hline $\begin{array}{c}\text { Main } \\
\text { Variable }\end{array}$ & Sub-Variables & Questionnaire & Cronbach's Alpha & Remarks \\
\hline \multirow{17}{*}{$\begin{array}{l}\text { Product } \\
\text { Quality }\end{array}$} & \multirow{3}{*}{$\begin{array}{l}\text { Performance } \\
\text { (X1) }\end{array}$} & $\mathrm{X} 1.1$ & 0.938 & Reliable \\
\hline & & $\mathrm{X} 1.2$ & 0.941 & Reliable \\
\hline & & $\mathrm{X} 1.3$ & 0.937 & Reliable \\
\hline & \multirow{2}{*}{$\begin{array}{c}\text { Reliability } \\
\text { (X2) }\end{array}$} & $\mathrm{X} 2.1$ & 0.937 & Reliable \\
\hline & & $\mathrm{X} 2.2$ & 0.937 & Reliable \\
\hline & \multirow{2}{*}{$\begin{array}{l}\text { Features } \\
\text { (X3) }\end{array}$} & $\mathrm{X} 3.1$ & 0.937 & Reliable \\
\hline & & $\mathrm{X} 3.2$ & 0.936 & Reliable \\
\hline & \multirow{2}{*}{$\begin{array}{c}\text { Conformance } \\
\text { (X4) }\end{array}$} & $X 4.1$ & 0.935 & Reliable \\
\hline & & $X 4.2$ & 0.935 & Reliable \\
\hline & \multirow{2}{*}{$\begin{array}{l}\text { Durability } \\
\text { (X5) }\end{array}$} & $\mathrm{X} 5.1$ & 0.939 & Reliable \\
\hline & & $\mathrm{X} 5.2$ & 0.940 & Reliable \\
\hline & \multirow{2}{*}{$\begin{array}{l}\text { Serviceability } \\
\text { (X6) }\end{array}$} & $\mathrm{X} 6.1$ & 0.939 & Reliable \\
\hline & & $\mathrm{X} 6.2$ & 0.938 & Reliable \\
\hline & \multirow{2}{*}{$\begin{array}{c}\text { Aesthetics } \\
X(7)\end{array}$} & $\mathrm{X} 7.1$ & 0.936 & Reliable \\
\hline & & $\mathrm{X} 7.2$ & 0.939 & Reliable \\
\hline & \multirow{2}{*}{$\begin{array}{c}\text { Perceived } \\
\text { Quality (X8) }\end{array}$} & $\mathrm{X} 8.1$ & 0.935 & Reliable \\
\hline & & $\mathrm{X} 8.2$ & 0.935 & Reliable \\
\hline
\end{tabular}

Source: Primary data (2021)

Table 8: Reliability test result towards the Customer Satisfaction variable

\begin{tabular}{|c|c|c|c|c|}
\hline $\begin{array}{c}\text { Main } \\
\text { Variable }\end{array}$ & Sub-Variables & Questionnaire & $\begin{array}{c}\text { Cronbach's } \\
\text { Alpha }\end{array}$ & Remarks \\
\hline \multirow{18}{*}{$\begin{array}{l}\text { Customer } \\
\text { Satisfaction }\end{array}$} & \multirow{3}{*}{$\begin{array}{c}\text { Service Quality } \\
\text { (Tangible) }\end{array}$} & Y1 & 0.932 & Reliable \\
\hline & & $Y 2$ & 0.930 & Reliable \\
\hline & & Y3 & 0.932 & Reliable \\
\hline & \multirow{4}{*}{$\begin{array}{l}\text { Service Quality } \\
\text { (Reliability) }\end{array}$} & Y4 & 0.931 & Reliable \\
\hline & & Y5 & 0.934 & Reliable \\
\hline & & Y6 & 0.930 & Reliable \\
\hline & & $Y 7$ & 0.932 & Reliable \\
\hline & \multirow{2}{*}{$\begin{array}{l}\text { Service Quality } \\
\text { (Responsiveness) }\end{array}$} & Y8 & 0.931 & Reliable \\
\hline & & Y9 & 0.931 & Reliable \\
\hline & \multirow{3}{*}{$\begin{array}{l}\text { Service Quality } \\
\text { (Assurance) }\end{array}$} & Y10 & 0.931 & Reliable \\
\hline & & Y11 & 0.932 & Reliable \\
\hline & & Y12 & 0.931 & Reliable \\
\hline & \multirow{2}{*}{$\begin{array}{l}\text { Service Quality } \\
\text { (Empathy) }\end{array}$} & Y13 & 0.933 & Reliable \\
\hline & & Y14 & 0.934 & Reliable \\
\hline & \multirow{2}{*}{ Price } & Y15 & 0.933 & Reliable \\
\hline & & Y16 & 0.933 & Reliable \\
\hline & \multirow{2}{*}{ Variety Product } & Y17 & 0.930 & Reliable \\
\hline & & Y18 & 0.932 & Reliable \\
\hline
\end{tabular}

Source: Primary data (2021) 


\section{E. Regression Analysis Classic Assumption test a) Normality Test}

Figure 6: Interpretation of Normal Probability Plot Test Output with SPSS

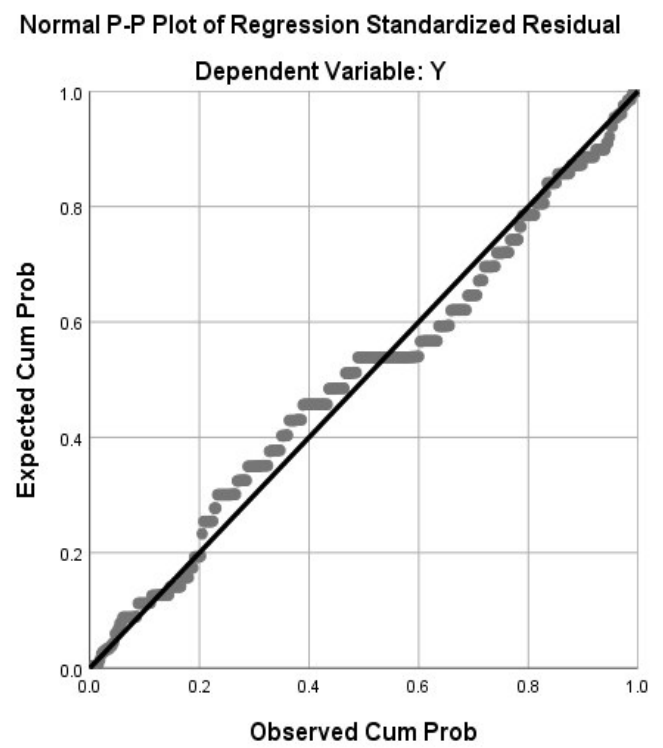

Figure 5.3.1.a: Normal Probability Plot

Based on the output Figure 6 above, we can see that the plot points in the image "Normal P-P Plot of Regression Standardized Residual" always follow and approach the diagonal line.

Therefore, as the basis or guideline for decision making in the probability plot technique normality test, it can be concluded that the residual value is normally distributed. Thus, the normality assumption for the residual value in the simple linear regression analysis in this study can be fulfilled. Aside from that Kolmogorov-Smirnov test can be shown in the following.

Table 9: Kolmogorov-Smirnov Test Results

\begin{tabular}{|l|l|r|}
\hline \multicolumn{2}{|c|}{} & $\begin{array}{c}\text { Unstandardized } \\
\text { Residual }\end{array}$ \\
\hline $\mathrm{N}$ & Mean & 359 \\
\cline { 2 - 3 } Normal Parametersa, b & Std. Deviation & 1.31357248 \\
\hline Most Extreme Differences & Absolute & .069 \\
\cline { 2 - 3 } & Positive & .068 \\
\cline { 2 - 3 } & Negative & -.069 \\
\hline Test Statistic & & .069 \\
\hline Asymp. Sig. (2-tailed) & \multicolumn{2}{|c}{ Source: SPSS output (2021) }
\end{tabular}

Based on the SPSS output table 9, it is known that the Asiymp.Sig (2-tailed) significance value is more than 0.086 greater than 0.05 . Then in accordance with the basis of taking the decision in the Kolmogorov-Smirnov normality test above, it can be concluded that the data are normally distributed. Therefore, the assumptions or normality requirements in the model regression is fulfilled. 


\section{b) Heteroscedasticity Test}

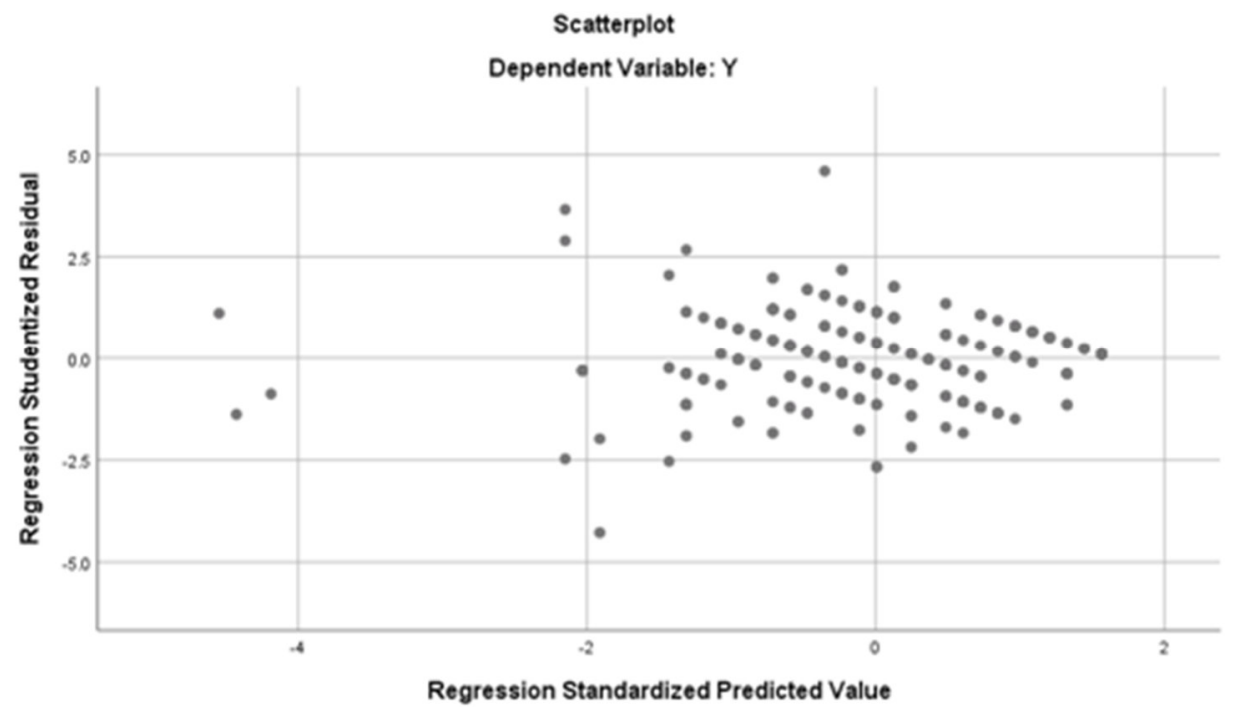

Figure 7: Scatter Plot

Based on the Scatterplots output above, it is known that:

1. The scatter data points are above and below or around the 0 number.

2. The dots don't cluster just above or below.

3. The spread of data points does not form a wavy pattern that widens then narrows and widened again.

4. The distribution of data points is not patterned.

Thus, it can be concluded that there is no heteroscedasticity problem, until a good and ideal regression model can be fulfilled.

\section{c) Multicollinearity test}

This test is used to test whether there is a relationship (correlation) between independent variables included in the regression model. A good regression model should not occur correlation between independent variables. The method used to detect the presence of multico-linearity symptoms is to observe the value of tolerance or VIF (variance inflation factor) if the tolerance value $<0.10$ or VIF value $>10$ then indicate the presence of multicollinearity symptoms.

Table 10: Multicollinearity Test Results

\begin{tabular}{|c|l|c|c|}
\hline No & Independent Variables & Tolerance & VIF (\%) \\
\hline 1 & Performance (X1) & 0.438 & 2.285 \\
\hline 2 & Reliability (X2) & 0.359 & 2.789 \\
\hline 3 & Feature(X3) & 0.227 & 4.413 \\
\hline 4 & Conformance (X4) & 0.134 & 7.442 \\
\hline 5 & Durability (X5) & 0.469 & 2.132 \\
\hline 6 & Serviceability (X6) & 0.364 & 2.746 \\
\hline 7 & Aesthetics (X7) & 0.366 & 2.732 \\
\hline 8 & Perceived Quality (X8) & 0.141 & 6.022 \\
\hline
\end{tabular}

Source: Primary data (2021)

From the Table 10, it can be shown that the VIF value of all independent variables in this study are less than the value of 10 , while the tolerance value of all independent variables is more than $10 \%$, which means that there is no correlation between independent variables whose value is more than $90 \%$, thus it can be concluded that there are no symptoms multicollinearity between independent variables in the regression model.

\section{d) Auto Correlation test}

The autocorrelation test is to test whether in a linear regression model there is a correlation between the confounding error in period $t$ and the error in period $t-1$ (previous). The autocorrelation test is used to determine whether or not there is a deviation from the autocorrelation cyclical assumption, namely the correlation that occurs between the residuals in one observation and another observation in the regression model, if there is a correlation, it is called an autocorrelation problem. The prerequisite that must be met is the absence of autocorrelation in the regression model. 
Table 11: Correlation Coefficient

\begin{tabular}{|l|r|r|r|r|r|}
\hline \multicolumn{7}{|c|}{ Model Summary $^{\mathrm{b}}$} \\
\hline Model & $\mathrm{R}$ & R Square & $\begin{array}{c}\text { Adjusted R } \\
\text { Square }\end{array}$ & $\begin{array}{c}\text { Std. Error of the } \\
\text { Estimate }\end{array}$ & Durbin-Watson \\
\hline 1 & $.989^{\mathrm{a}}$ & .979 & .978 & 1.429 & 1.821 \\
\hline a. Predictors: (Constant), Performance (X1), Reliability (X2), Feature (X3), Conformance (X4), \\
Durability (X5), Serviceability (X6), Aesthetics (X7), Perceived Quality (X8) \\
\hline b. Dependent Variable: Y (Customer Satisfaction) \\
\hline
\end{tabular}

Source: SPSS results

From the test results shown in the table 11, shows that the Durbin Watson value is 1 . The model does not occur autocorrelation if the Durbin Watson value is between 1.55 and 2.46. This shows that there is no autocorrelation.

\section{Multiple Linear Regression Analysis}

Table 12: Simple Linear Regression Results Analysis

\begin{tabular}{|c|c|c|c|c|c|c|c|c|}
\hline \multicolumn{9}{|c|}{ Coefficients $^{a}$} \\
\hline \multirow{2}{*}{\multicolumn{2}{|c|}{ Model }} & \multicolumn{2}{|c|}{$\begin{array}{l}\text { Unstandardized } \\
\text { Coefficients }\end{array}$} & \multirow{2}{*}{$\begin{array}{c}\text { Standardized } \\
\text { Coefficients } \\
\text { Beta }\end{array}$} & \multirow[t]{2}{*}{$t$} & \multirow{2}{*}{ Sig. } & \multicolumn{2}{|c|}{$\begin{array}{l}\text { Collinearity } \\
\text { Statistics }\end{array}$} \\
\hline & & $\mathrm{B}$ & Std. Error & & & & Tolerance & VIF \\
\hline$\overline{1}$ & (Constant) & 2.906 & 0.585 & & 4.966 & .000 & & \\
\hline & Performance (X1) & 1.250 & 0.058 & 0.251 & 21.407 & .000 & 0.438 & 2.285 \\
\hline & Reliability (X2) & 1.194 & 0.097 & 0.159 & 12.280 & .000 & 0.359 & 2.789 \\
\hline & Feature(X3) & 0.986 & 0.118 & 0.136 & 8.345 & .000 & 0.227 & 4.413 \\
\hline & Conformance (X4) & -0.126 & 0.136 & -0.020 & -0.924 & .356 & 0.134 & 7.442 \\
\hline & Durability (X5) & 1.265 & 0.075 & 0.192 & 16.928 & .000 & 0.469 & 2.132 \\
\hline & Serviceability $(\mathrm{X} 6)$ & 0.871 & 0.094 & 0.119 & 9.269 & .000 & 0.364 & 2.746 \\
\hline & Aesthetics (X7) & 1.512 & 0.089 & 0.218 & 16.975 & .000 & 0.366 & 2.732 \\
\hline & Perceived Quality (X8) & 1.068 & 0.157 & 0.167 & 6.800 & .000 & 0.141 & 6.022 \\
\hline
\end{tabular}

Source: SPSS results

From the table 12, it is known that the value of Constant is 2.906, where the coefficient of Performance (X1) is 1.250 , Reliability (X2) is 1.194 , Feature (X3) is 0.986 , Conformance (X4) is -0.126 , Durability (X5) is 1.265 , Serviceability (X6) is 0.871 , Aesthetics (X7) is 1.512 and Perceived Quality (X8) is 1.068 .

$Y=a+b_{1} x_{1}+b_{2} x_{2}+b_{3} x_{3}+b_{4} x_{4}+b_{5} x_{5}+b_{6} x_{6}+b_{7} x_{7}+b_{8} x_{8}$

$Y=2.906+1.250 x_{1}+1.194 x_{2}+0.986 x_{3}-0.126 x_{4}+1.265 x_{5}+0.871 x_{6}+1.512 x_{7}+1.068 x_{8}$

From the Equation stated above, it can be interpreted as the following:

- This equation can be Interpreted: The constant is 2.906; meaning that the value of the constants (a) is 2.906 that is, if the Performance (X1), Reliability (X2), Feature (X3), Conformance (X4), Durability (X5), Serviceability (X6), Aesthetics (X7), Perceived Quality (X8) are of value 0 (zero), then customer satisfaction is worth 2.906 points.

- The regression coefficient from the sub-variable performance $\left(\mathrm{X}_{1}\right)$ is about 1.250 which means that for every $1 \%$ increase in the value of the performance $\left(\mathrm{X}_{1}\right)$, the Customer Satisfaction value increases by 1.250

- The regression coefficient from the sub-variable Reliability $\left(\mathrm{X}_{2}\right)$ is about 1.194 which means that for every $1 \%$ increase in the value of the performance $\left(X_{2}\right)$, the Customer Satisfaction value increases by 1.194

- The regression coefficient from the sub-variable Feature $\left(\mathrm{X}_{3}\right)$ is about 0.986 which means that for every $1 \%$ increase in the value of the Feature $\left(\mathrm{X}_{3}\right)$, the Customer Satisfaction value increases by 0.986 points.

- The regression coefficient from the sub-variable Conformance $\left(\mathrm{X}_{4}\right)$ is about 0.126 which means that for every $1 \%$ increase in the value of the Conformance $\left(\mathrm{X}_{4}\right)$, the Customer Satisfaction value decreases by 0.126 points.

- The regression coefficient from the sub-variable Durability $\left(\mathrm{X}_{5}\right)$ is about 1.265 which means that for every $1 \%$ increase in the value of the Durability $\left(\mathrm{X}_{5}\right)$, the Customer Satisfaction value increases by 1.265 points.

- The regression coefficient from the sub-variable Serviceability $\left(\mathrm{X}_{6}\right)$ is about 0.871 which means that for every $1 \%$ increase in the value of the Serviceability $\left(\mathrm{X}_{6}\right)$, the Customer Satisfaction value increases by 0.871 points.

- The regression coefficient from the sub-variable Aesthetics $\left(X_{7}\right)$ is about 1.512 which means that for every $1 \%$ increase in the value of the Aesthetics $\left(\mathrm{X}_{7}\right)$, the Customer Satisfaction value increases by 1.512 points.

- The regression coefficient from the sub-variable Perceived Quality $\left(\mathrm{X}_{8}\right)$ is about 1.068 which means that for every $1 \%$ increase in the value of the Perceived Quality $\left(\mathrm{X}_{8}\right)$, the Customer Satisfaction value increases by 
1.068 points.

- The regression coefficients of the sub-variables are mostly positive, so it can be concluded that the direction of the influence of variable $\mathrm{X}$ to $\mathrm{Y}$ is positive.

\section{Hypothesis test}

1) Partial Significance test (t-test)

Table 13: Coefficient

\begin{tabular}{|c|c|c|c|c|c|c|c|c|}
\hline \multicolumn{9}{|c|}{ Coefficients $^{a}$} \\
\hline & \multirow{2}{*}{ Model } & \multicolumn{2}{|c|}{$\begin{array}{c}\text { Unstandardized } \\
\text { Coefficients }\end{array}$} & \multirow{2}{*}{$\begin{array}{c}\text { Standardized } \\
\text { Coefficients } \\
\text { Beta }\end{array}$} & \multirow[t]{2}{*}{$t$} & \multirow{2}{*}{ Sig. } & \multicolumn{2}{|c|}{$\begin{array}{c}\text { Collinearity } \\
\text { Statistics }\end{array}$} \\
\hline & & $\mathrm{B}$ & Std. Error & & & & Tolerance & VIF \\
\hline 1 & (Constant) & 2.906 & 0.585 & & 4.966 & .000 & & \\
\hline & Performance (X1) & 1.250 & 0.058 & 0.251 & 21.407 & .000 & 0.438 & 2.285 \\
\hline & Reliability (X2) & 1.194 & 0.097 & 0.159 & 12.280 & .000 & 0.359 & 2.789 \\
\hline & Feature(X3) & 0.986 & 0.118 & 0.136 & 8.345 & .000 & 0.227 & 4.413 \\
\hline & Conformance (X4) & -0.126 & 0.136 & -0.020 & -0.924 & .356 & 0.134 & 7.442 \\
\hline & Durability (X5) & 1.265 & 0.075 & 0.192 & 16.928 & .000 & 0.469 & 2.132 \\
\hline & Serviceability (X6) & 0.871 & 0.094 & 0.119 & 9.269 & .000 & 0.364 & 2.746 \\
\hline & Aesthetics (X7) & 1.512 & 0.089 & 0.218 & 16.975 & .000 & 0.366 & 2.732 \\
\hline
\end{tabular}

From the table above, it can be known that:

Source: SPSS results

a) Variable Performance $\left(\mathrm{X}_{1}\right)$

In accordance with the results of the calculation of the $t$ test carried out with the help of the SPSS program above in table 13, the sub-variable performance $(X 1)$ has a $t_{\text {value }}>t_{\text {table }}(4.966>1.6495)$ with a significance value of 0.000 . So, this significance value is smaller than the value of $\alpha=0.05$. Therefore, the value $(\operatorname{sig}<\alpha=0,000<0.05)$, the independent variable, namely performance (X1) partially affects the dependent variable, namely Customer Satisfaction. Therefore, $\mathrm{H} 1$ is accepted.

b) Variable Reliability $\left(\mathrm{X}_{2}\right)$

From the $t$ test results that can be seen from the table 13, it is known that the sub-variable reliability (X2) has a $t_{\text {value }}>t_{\text {table }}(21.407>1.6495)$ with a significance value of 0.000 . So, this significance value is smaller than the value of $\alpha=0.05$. Therefore, the value ( $\operatorname{sig}<\alpha=0,000<0.05$ ), the independent variable, namely reliability (X2) partially affects the dependent variable, namely Customer Satisfaction. Therefore, $\mathrm{H} 2$ is accepted.

c) Variable Feature $\left(\mathrm{X}_{3}\right)$

According to the $\mathrm{t}$ test results that is shown in the table 13, it can be shown that the sub-variable namely, Feature $(\mathrm{X} 3)$ has a $t_{\text {value }}>t_{\text {table }}(8.345>1.6495)$ with significance value of 0.000 . So, this significance value is smaller than the value of $\alpha=0.05$. Therefore, the value ( $\operatorname{sig}<\alpha=0,000<0.05$ ), the independent variable, namely Feature (X3) partially affects the dependent variable, namely Customer Satisfaction. Therefore, H3 is accepted.

d) Variable Conformance $\left(\mathrm{X}_{4}\right)$

From the $\mathrm{t}$ test which was conducted in the SPSS program, the results can be seen in table 13, which shows that the sub-variable Conformance $(\mathrm{X} 4)$ has a $t_{\text {value }}>t_{\text {table }}(-0.924>1.6495)$ with significance value of 0.356 which is much greater than the value of $\alpha=0.05$. Therefore, the value ( $\operatorname{sig}>\alpha=0.356>0.05)$, the independent variable, namely Conformance (X4) does not partially affect the dependent variable, namely Customer Satisfaction. Therefore, $\mathrm{H} 4$ is rejected.

e) Variable Durability $\left(\mathrm{X}_{5}\right)$

Through the utilization of SPSS program in processing the $t$ test, the result that is obtained for the sub-variable durability $(\mathrm{X} 5)$ was shown to have a $t_{\text {value }}>t_{\text {table }}(16.928>1.6495)$ with a significance value of 0.000 which is smaller than the value of $\alpha=0.05$. Therefore, it can be concluded that the value ( $\operatorname{sig}<\alpha=0.000<0.05$ ), the independent variable, durability $\left(\mathrm{X}_{5}\right)$ partially affects the dependent variable, Customer Satisfaction. Therefore, H5 is accepted.

f) Variable Serviceability $\left(\mathrm{X}_{6}\right)$

By using the SPSS program, the results of the $t$ test for the sub-variable Serviceability (X6) were known to have a $\mathrm{t}_{\text {value }}>\mathrm{t}_{\text {table }}(9.269>1.6495)$ with significance value of 0.000 which is lower than the value $\alpha=0.05$. In a nutshell, the value $(\operatorname{sig}<\alpha=0.000<0.05)$, the independent variable, Serviceability $\left(\mathrm{X}_{6}\right)$ partially affects the dependent variable, Customer Satisfaction. Therefore, H6 is accepted.

g) Variable Aesthetics $\left(\mathrm{X}_{7}\right)$

According to the $\mathrm{t}$ test results that is shown in the table 13, it can be shown that the sub-variable namely, Aesthetics $(X 7)$ has a $t_{\text {value }}>t_{\text {table }}(16.975>1.6495)$ with significance value of 0.000 . So, this significance value is smaller than 
the value of $\alpha=0.05$. Therefore, the value ( $\operatorname{sig}<\alpha=0,000<0.05$ ), the independent variable, namely Aesthetics (X7) partially affects the dependent variable, namely Customer Satisfaction. Therefore, H7 is accepted.

h) Variable Perceived Quality $\left(\mathrm{X}_{8}\right)$

In accordance with the results of the calculation of the $t$ test carried out with the help of the SPSS program above, the sub-variable Perceived Quality $(X 8)$ has a $t_{\text {value }}>t_{\text {table }}(6.800>1.6495)$ with significance value of 0.000 . So, this significance value is smaller than the value of $\alpha=0.05$. Therefore, the value ( $\operatorname{sig}<\alpha=0,000<0.05$ ), the independent variable, namely Perceived Quality (X8) partially affects the dependent variable, namely Customer Satisfaction. Therefore, H8 is accepted.

\section{2) Simultaneous Significance test (F-test)}

From the data output shown in the ANOVA Table 14, it is shown that the value of $F_{\text {value }}>F_{\text {table }} 2035.299>1.965$ with the significant value of $0.000<0.05$ thus it can be deduced that the regression model is eligible to predict the dependent variable Y, in other words, Performance (X1), Reliability (X2), Feature (X3), Conformance (X4), Durability (X5), Serviceability (X6), Aesthetics (X7), Perceived Quality (X8) simultaneously affects the dependent variable Customer Satisfaction (Y) variable. Therefore, it can also be concluded that Belt and Road Initiative (BRI) through Indonesia's E-Commerce Platform Tokopedia, Product Quality of the product (made in china) is positively correlated and has a significant effect towards the Customer Satisfaction, thus H9 is accepted.

Table 14: Simultaneous Significance test results

\begin{tabular}{|c|c|c|c|c|c|c|}
\hline \multicolumn{7}{|c|}{ ANOVA ${ }^{\mathrm{a}}$} \\
\hline & Sum of Squares & \multirow{2}{*}{ df 8} & \multirow{2}{*}{$\begin{array}{r}\text { Mean Square } \\
4154.135 \\
\end{array}$} & \multirow{2}{*}{$\frac{\mathrm{F}}{2035.299}$} & \multirow{2}{*}{$\begin{array}{l}\text { Sig. } \\
.000\end{array}$} \\
\hline \multirow[t]{3}{*}{1} & odel & 33233.083 & & & & \\
\hline & \multirow{2}{*}{\begin{tabular}{|l|} 
Residual \\
Total
\end{tabular}} & 714.365 & 350 & \multirow[t]{2}{*}{2.041} & & \\
\hline & & 33947.448 & 358 & & & \\
\hline \multicolumn{7}{|c|}{ a. Dependent Variable: Y (Customer Satisfaction) } \\
\hline
\end{tabular}

Source: Primary Data (2021)

\section{3) Multiple Correlation Coefficient, $\boldsymbol{R}$}

Multiple correlation analysis is utilized to calculate the level of closeness of the relationship between the independent variable and the dependent variable. Multiple correlation analysis is used to measure the degree of closeness of the relationship between the independent variable (independent) and the dependent variable (dependent). The simultaneous coefficient of determination is the result of the square of the correlation coefficient that shows the percentage of the influence of the independent variables simultaneously on the dependent variable. The results of SPSS calculations regarding multiple correlation analysis are shown in the table below.

Table 15: Coefficients of Determination

\begin{tabular}{|l|r|r|r|r|r|}
\hline \multicolumn{7}{|c|}{ Model Summary $^{\mathrm{b}}$} \\
\hline Model & \multicolumn{1}{|c|}{$\mathrm{R}$} & R Square & $\begin{array}{c}\text { Adjusted R } \\
\text { Square }\end{array}$ & $\begin{array}{c}\text { Std. Error of the } \\
\text { Estimate }\end{array}$ & Durbin-Watson \\
\hline 1 & $.989^{\mathrm{a}}$ & .979 & .978 & 1.429 & 1.821 \\
\hline
\end{tabular}

a. Predictors: (Constant), Performance (X1), Reliability (X2), Feature (X3), Conformance (X4), Durability (X5), Serviceability (X6), Aesthetics (X7), Perceived Quality (X8) b. Dependent Variable: $\mathrm{Y}$ (Customer Satisfaction)

Source: Primary Data (2021)

It can be seen that the coefficient of determination (R square) is 0.983 or $98.3 \%$, in other words, Performance (X1), Reliability (X2), Feature (X3), Conformance (X4), Durability (X5), Serviceability (X6), Aesthetics (X7), Perceived Quality (X8) simultaneously affects the dependent Customer Satisfaction (Y) variable. Thus, it can be concluded that BRI through the Indonesian E-commerce platform, Tokopedia, product quality that are made in China, $\mathrm{X}$ has a positive and significant influence contribution of $98.3 \%$ towards the Customer Satisfaction and $0.7 \%$ are influenced by other factors.

4) Coefficients of Determinations $\left(\boldsymbol{R}^{2}\right)$

Multiple R-squared is used to calculate the ability of the regression model to explain how well the regression model fits the observed data which in this case would be the dependent variable with various the independent variables. If the $\mathrm{R}^{2}$ is getting closer to 1 or $100 \%$, it means that the regression model is better at explaining the 
variability of the dependent variable. The percentage of the influence of the independent variables on the dependent variable is shown by the coefficient of simultaneous determination $\left(\mathrm{R}^{2}\right)$. In this study, the magnitude of the $\mathrm{R}$ Square is 0.979 . This means that the rise and fall of the dependent variable, namely performance (Y), is influenced by the independent variables, namely Performance (X1), Reliability (X2), Feature (X3), Conformance (X4), Durability (X5), Serviceability (X6), Aesthetics (X7), Perceived Quality (X8) by $97.9 \%$ while the remaining 2.1 percent is influenced by other variables outside of this study.

\section{Discussions}

Throughout this study, the author has determined factors that would prove the benefits of (BRI) towards Indonesia E-commerce platform, TOKOPEDIA from the Customer satisfaction evaluation perspective. It is recommended that for future research, the researcher could add more factors or dissect further in-depth various factors regarding BRI towards TOKOPEDIA or other E-commerce platforms in Indonesia. This study is conducted towards Indonesian who have at least used Tokopedia once and residing in Indonesia. The author recommended for future researcher to study the impact according to the respective regions in Indonesia for better outcome and more accurate results. When conducting this study, the author uses the product quality and customer satisfaction evaluation as the keyword to understand the effect of BRI towards TOKOPEDIA, it is suggested that future researcher would try and further dissect the possible key determinants that might be affected by the BRI since in this study the author only uses the 8 dimensions of the product quality to find out the effect of BRI towards the customer satisfaction of Tokopedia namely Performance (X1), Reliability (X2), Feature (X3), Conformance (X4), Durability (X5), Serviceability (X6), Aesthetics (X7), Perceived Quality (X8). From the research results in this study, there are some recommendations that can be taken to sustain the excellence of Tokopedia Customer Satisfaction towards the products that are made in China thus showing more obvious benefits and positive impacts of the Belt and Road Initiative in the Indonesian E-commerce platform, Tokopedia and its consumer.

Table 16: Significance table

\begin{tabular}{|c|l|c|l|}
\hline No & \multicolumn{1}{|c|}{ Variables X } & Variable Y & Significance \\
\hline 1 & Performance & Customer Satisfaction & Positive \\
\hline 2 & Reliability & Customer Satisfaction & Positive \\
\hline 3 & Feature & Customer Satisfaction & Positive \\
\hline 4 & Conformance & Customer Satisfaction & Negative \\
\hline 5 & Durability & Customer Satisfaction & Positive \\
\hline 6 & Serviceability & Customer Satisfaction & Positive \\
\hline 7 & Aesthetics & Customer Satisfaction & Positive \\
\hline 8 & Perceived Quality & Customer Satisfaction & Positive \\
\hline
\end{tabular}

In reference with the research results, the variable Performance (X1) is known to have a positive influence towards the Customer satisfaction. In other words, Performance of the Products (made In China) that are offered through the E-commerce Platform, Tokopedia plays a crucial role in determining satisfaction of the customers. Since the results is positive therefore, the author recommended that Tokopedia to maintain its products (made in China) performance by conducting more creative marketing to keep its recognition from customers. Providing accurate information regarding the products offered by the sellers, improve the product visibility towards the customers in Tokopedia.

The second variable, reliability (X2) is known to have a positive influence towards the Customer Satisfaction. Reliability refers to products' level of usefulness which therefore, can be understood that the level of usefulness of the products (made in China) offered in Tokopedia shows a satisfactory result in the perceptions of the Indonesian customers.

The third variable, Feature (X3) has a positive significant result towards the Customer Satisfaction. Feature in this study refers to the added value to the products (made in China) offered in Tokopedia. The author recommended that Tokopedia could improve the features of the products (made in China) offered by assisting the customers in getting the best products offered through its products sorting algorithm which will make it more convenient for the customers to search for the desired products accurately.

The fourth variable, Conformance (X4) has a negative impact towards the Customer Satisfaction. Conformance in this research refers to the conformance to a specified standard of products (made in China) offered in Tokopedia. There might be some cases in which the products received by the customer was below expectations 
due to the lack of clear information stated by the products specifications listed in Tokopedia. Therefore, it is recommended for Tokopedia to improve its products sorting system so that the products (made in China) that are offered are the top-quality products which conform according to the specified standard.

The fifth variable, Durability (X5) exhibited a positive impact to the customer satisfaction. Durability can be understood as the capacity of the product to be able to function well normally over the course of its design lifespan without needing unnecessary maintenance or repair. Therefore, in order to maintain the excellence quality of the products (made in China) durability offered in Tokopedia, Tokopedia has to provide more incentives to the seller whose products (made in China) have a good durability standard so to motivate the local seller to keep the durability standard of the products.

The sixth variable, Serviceability (X6) also shown a positive impact to the level of the Customer Satisfaction. In this case, Serviceability refers to how adequate is the service offered by the seller of the products (made in China) in Tokopedia to the customers. Therefore, Tokopedia can maintain the excellence of its serviceability by improving the platform service towards the customers through conducting more promotional activities, reduce the risks for the customer to provide personal data during the shopping activities.

The seventh variable, Aesthetics (X7) can be found to impact the customer satisfaction positively. In this study, Aesthetics refers to the various forms of the products offered as well as the neatness and the refinement of the products (made in China) offered in Tokopedia. Therefore, Tokopedia should improve its platform in presenting the products listed in the platform more visually pleasing and exquisite which is in reference to this study would improve the customer satisfaction.

The last variable, Perceived Quality (X8) is found to have a positive impact towards the customer satisfaction. In reference of this research study, perceived quality is known to be the consumer's impression after using the product itself. Products that can work well and in accordance with the expectations or perceptions of consumers will create a good impression, because consumers are satisfied with the product's performance. The implication is that consumers will be loyal to the company's products. On the contrary, if the product does not work in accordance with consumer expectations, the consumer will feel less satisfied thus will be less loyal. Therefore, the researcher recommended that Tokopedia may improve its products offered by the seller by providing good products suppliers towards the products sellers

\section{Conclusion}

\section{To investigate the impacts and benefits of The Belt and Road Initiative towards the market place of} TOKOPEDIA company in Indonesia using Customer Satisfaction.

Quality of Chinese products are proven to have a positive significant impact on the customer satisfaction of the Indonesian consumer in Tokopedia. It can be seen from the result of the eight dimensions of the product quality that were discussed earlier.

Since in the result of the respective dimensions of product quality referring to the Chinese products offered in the Indonesian E-commerce platforms, Tokopedia are mostly positive therefore, it can also be concluded that the belt and road initiative have been beneficial towards Tokopedia.

From the quality of the Chinese products offered in Tokopedia, Indonesian Consumers' satisfaction is found to be mostly positive which shows that Indonesian consumers are enjoying the benefits of the Chinese products purchased in terms of its Performance (X1), Reliability (X2), Feature (X3), Conformance (X4), Durability (X5), Serviceability (X6), Aesthetics (X7), Perceived Quality (X8) which are also brought by the Belt and Road Initiative. To classify the market place of TOKOPEDIA platform's e-commerce projects under The Belt and Road Initiative using Customer Satisfaction.

According to the result above, Indonesian consumers are found to be satisfied with the features offered in the Chinese products offered in Tokopedia which can be concluded through the Belt and Road Initiative, more and more inflow of Chinese products into Indonesia resulting into varieties of products features that are also available in Tokopedia, in this way the market place of Tokopedia platforms are becoming more Business to consumers concentrated marketplace.

To analyze the market place of TOKOPEDIA platform's development under The Belt and Road Initiative as a sample for the investigation of the development of e-commerce in Indonesia using Customer Satisfaction. The market place of Tokopedia e-commerce platforms is becoming more and more consumers to consumers oriented due to the positive responses towards the Chinese products thereby increasing the demands of Chinese goods in the market therefore, more and more sellers to be much eager in importing Chinese goods to the Indonesian consumers. However, the downside of the business to consumers marketplace is the over-crowding of the Chinese goods in Tokopedia which will cause a rigorous competition among the sellers. In the long term, as the Belt and Road Initiatives ecosystem matures, it is predicted that more Chinese applications, goods and services will make their outbound journeys and more Chinese cultural material, objects, fashion items, trends and innovations will become more widespread and permissible in foreign markets especially in Indonesia. Therefore, Tokopedia will have to catch up with the on-going trends of the new digital silk road era to secure more funds and 
becoming capable e-commerce player locally and internationally in the market.

To provide possible advices based on surveys to support the development of the market place of TOKOPEDIA platform's system under The Belt and Road Initiative, which could possibly be a consideration to other platforms as well based on Customer Satisfaction.

Under the Belt and Road Initiative, Alibaba (the largest e-commerce platform in Southeast Asia) has been capable of investing in Indonesia's e-commerce platform easily. In an effort to enhance and expand the Alibaba market, Alibaba deepens the integration of its ecosystem by investing a total of $\$ 1.1$ billion in Tokopedia. Tokopedia is considered to be the largest e-commerce marketplace in the Indonesian region. Since from the survey distributed amongst Tokopedia users, Chinese products are more than capable in satisfying the demands of the Indonesian consumers under the product quality dimensions. Thus, Tokopedia sustain their service in maintaining the quality of the Chinese products offered in their platform and reaps more benefits from the ongoing projects of the belt and road Initiative which in turn will also further improve Tokopedia to become the top Indonesian e-commerce platforms.

\section{References}

Garvin, D. A. (1984). What does "product quality" really mean? Sloan Management Review (pre-1986). Fall Harvard University.

Jarvenpaa, S., \& Todd, P. (1996). Consumer reactions to electronic shopping on the world wide web. International Journal of Electronic Commerce, 1(2), 59-88.[2]

Sproles, G. B., \& Kendall, E. L. (1986). A methodology for profiling consumers' decision-making styles. Journal of Consumer Affairs, 20(2), 267-279.[3]

Schaupp, L. C., \& Belanger, F. (2005). A conjoint analysis of online consumer satisfaction. Journal of Electronic Commerce Research, 6(2), 95-111.[4]

Man Hung Thomas Chan (2018) The Belt and Road Initiative - the New Silk Road: a research agenda, Journal of Contemporary East Asia Studies, 7:2, 104-123, DOI: 10.1080/24761028.2019.1580407[5]

Ong, T. (2018). Chinese social media giant WeChat reaches 1 million. The Verge. Available at: https://www.theverge.com/2018/3/5/17080546/wechat-chinese-social-media-billion-users-china Accessed on 27 February 2021.[6]

Shen, H. (2018). Building a digital Silk Road? Situating the Internet in China's Belt and Road Initiative. International Journal of Communication, 12, 2683-2701. Available at: https://ijoc.org/index.php/ijoc/article/view/8405

Russell, J. (2017). Alibaba leads $\$ 1.1 B$ investment in Indonesia-based e-commerce firm Tokopedia Available at: https://techcrunch.com/2017/08/17/alibaba-tokopedia/ Accessed on 27 February 2021.[8]

Melati, K.R. and Nur Komala Dewi, S.P. (2020). Integrated E-Commerce Ecosystem in China and Indonesia's Giant Market. Proceedings of the 2nd International Media Conference 2019 (IMC 2019). [online] Available at: https://www.atlantis-press.com/proceedings/imc-19/125938025 Accessed on: 28 February 2021.[9]

Bryman, A., \& Bell, E. (2015). Business research methods. Oxford University Press, USA.[10] Parasuraman, A., Zeithaml, V. A. (2005). ES-QUAL: A multiple-item scale for assessing electronic service quality. Journal of service research, 7(3), 213-233.[11]

Zeithaml, V. A., Parasuraman, A., \& Malhotra, A. (2002). Service quality delivery through web sites: a critical review of extant knowledge. Journal of the academy of marketing science, 30(4), 362[12]

Anderson, E. W., \& Lehmann, D. R. (1994). Customer satisfaction, market share, and profitability: Findings from Sweden. The Journal of marketing, 53-66.[13]

Heo, C. Y., \& Lee, S. (2011). Influences of consumer characteristics on fairness perceptions of revenue management pricing in the hotel industry. International Journal of Hospitality Management, 30(2), 243251.[14]

Szymanski, D. M., \& Hise, R. T. (2000). E-Satisfaction: an initial examination. Journal of Retailing, 76(3), 309-322. http://dx.doi.org/10.1016/S0022-4359(00)00035-X [15]

Chung K, Shin J. (2010). The antecedents and consequences of relationship quality in internet shopping. Asia Pacific Journal of Marketing and Logistics. 22(4), 473-491. [16]

Ali, P. (2011). "Online Shopping" Customer Satisfaction and Loyalty in Norway Available at: https://www.semanticscholar.org/paper/“Online-Shopping”-Customer-Satisfaction-and-LoyaltyAli/afb09b41c8f92c783294c0b7a525352cdab803d1 [17]

Abdeldayem, M.M. (2010). A study of customer satisfaction with online shopping: evidence from the UAE. International Journal of Advanced Media Community. 4, 235-257. 